\title{
Some Growth Parameters of Five Fish Species in the Lower Sakarya River, Turkey
}

\author{
İsmail Reis ${ }^{1}$ (D), Hasan Cerim ${ }^{1}$ (D), Celal Ateş ${ }^{1}$ (D)
}

Cite this article as: Reis, I., Cerim, H., Ateş, C. (2020). Some growth parameters of five fish species in the lower Sakarya river, Turkey. Aquatic Sciences and Engineering, 35(3), 75-82.

ORCID IDs of the author: i.R. 0000-0003-4599-6780; H.C. $0000-0003-3025-1444$ C.A. $0000-0002-7336-0387$

${ }^{1}$ Muğla Sıtkı Koçman University Fisheries Faculty, Department of Fishing Technology, Muğla, Turkey

Submitted:

26.11.2019

Revision Requested:

29.02.2020

Revision Requested: 09.03.2020

Accepted:

20.03.2020

Online published:

06.04.2020

Correspondence:

İsmail Reis

E-mail:

ismailreis@mu.edu.tr

(C) Copyright 2020 by Aquatic

Sciences and Engineering

Available online at

https://dergipark.org.tr/ase

\begin{abstract}
In this study, a total of 1283 samples of five fish species belonging to two families, Cyprinidae and Leuciscidae, were collected from the Lower Sakarya River between June 2017 and May 2018 in order to determine some growth parameters. The samples were collected monthly with trammel net, fykenets, and electro shocker. The age of the fish was determined from the scales. The von Bertalanffy's growth model was calculated $L t=92.18\left(1-\mathrm{e}^{-0.054(t+0.040)}\right)$ for $A$. brama, $L t=69.40\left(1-e^{-0.040(t+0.030)}\right)$ for B. bjoerkna, Lt $=51.09\left(1-\mathrm{e}^{-0.114(t+0.024)}\right)$ for C. gibelio, $L t=48.11\left(1-\mathrm{e}^{-0.088(t+0.023)}\right)$ for $R$. rutilus and $L t=$ $41.74\left(1-e^{-0.104(t+0.035)}\right)$ for $V$. vimba. The phi-prime growth performance index $\left(\Phi^{\prime}\right)$ value was computed as 2.628, 2.268, 2.474, 2.307 and 2.260 for A. brama, B. bjoerkna, C. gibelio, R. rutilus and V. vimba, respectively. This study provides basic information on some growth parameters of five fish species living in the Lower Sakarya River. The results of this study are useful for fishery managements and stock assessment in the Sakarya River.
\end{abstract}

Keywords: Age and growth, cyprinidae, leuciscidae, fishery management, Sakarya River

\section{INTRODUCTION}

Rivers and natural lakes are important ecosystems of our world and cover approximately $2.5 \%$ of the earth's surface (Shiklomanov, 1999). Turkey has important freshwater resources and one of these freshwater resources is the Sakarya River. The Sakarya River basin $(58000$ km²), one of the majör rivers pouring into the Black Sea, covers approximately $7 \%$ of Turkey's surface area $\left(783000 \mathrm{~km}^{2}\right)$. Its average flow rate is about $190 \mathrm{~m}^{3}$ per second. The water temperature changes between 7 to $24{ }^{\circ} \mathrm{C}$ through out the year. The river basin is divided into three regions named Lower, Mid and Upper Basin (Şengörür \& İsa, 2001).

Cyprinidae is found in North America (from northern Canada to southern Mexico), Africa, and Eurasia. Cyprinidae is the largest family of freshwater fish with 346 genera and 3,170 species in the world. Leuciscidae is the other important freshwater fish with 90 genera and 672 species (Eschmeyer, Fricke \& van der Laan, 2017). Various researches have been carried out on the fish species living in the Sakarya River and its tributaries. (Ölmez, 1992; Emiroğlu, 2011; Kahraman, Göktürk \& Aydın, 2014; Korkmaz \& Zencir Tanır, 2016; Memiş, Tosun, Yamaner, Tunçelli \& Gessner, 2019; Reis, Cerim \& Ateş, 2019).

Age and growth are related with each other. Age gives a knowledge about sexual maturity, spawning period, fish size, growth rate and lifespan. Knowledge of all these parameters are important data for fisheries management and vary among populations. Accurate age determination and estimates of growth parameters are fundamental requirements for understanding population dynamics and maintaining sustainable yields in fisheries biology (Campana \& Thorrold, 2001).

In this study, some growth parameters were determined for Abramis brama (Linnaeus, 1758), 
Blicca bjoerkna (Linnaeus, 1758), Carassius gibelio (Bloch, 1782), Rutilus rutilus (Linnaeus, 1758) and Vimba vimba (Linnaeus, 1758) that were caught in the lower Sakarya River. These datas contribute to the sustainable management of the Sakarya River fisheries.

\section{MATERIALS AND METHODS}

This study was carried out between June 2017 and May 2018 in the $159.5 \mathrm{~km}$ section of the Sakarya River within the borders of Sakarya province. The aforementioned section includes Mekece in the south of Pamukova and Karasu Yenimahalle, where it deposits into the Black Sea.

The samples were collected monthly with trammel nets (inner panel: 52-72-88 mm, outer panel: $300 \mathrm{~mm}$; stretched mesh sized), fyke net (140 mm stretched mesh sized, $5 \mathrm{~m}$ leader net) and electro shocker (SAMUS 1000; 500W) from the three stations (Pamukova, Adapazarı and Karasu) identified in the lower Sakarya River Basin (Figure 1). The sampling areas were sandy-muddy substrates and depths were between 1.5-10 meters.

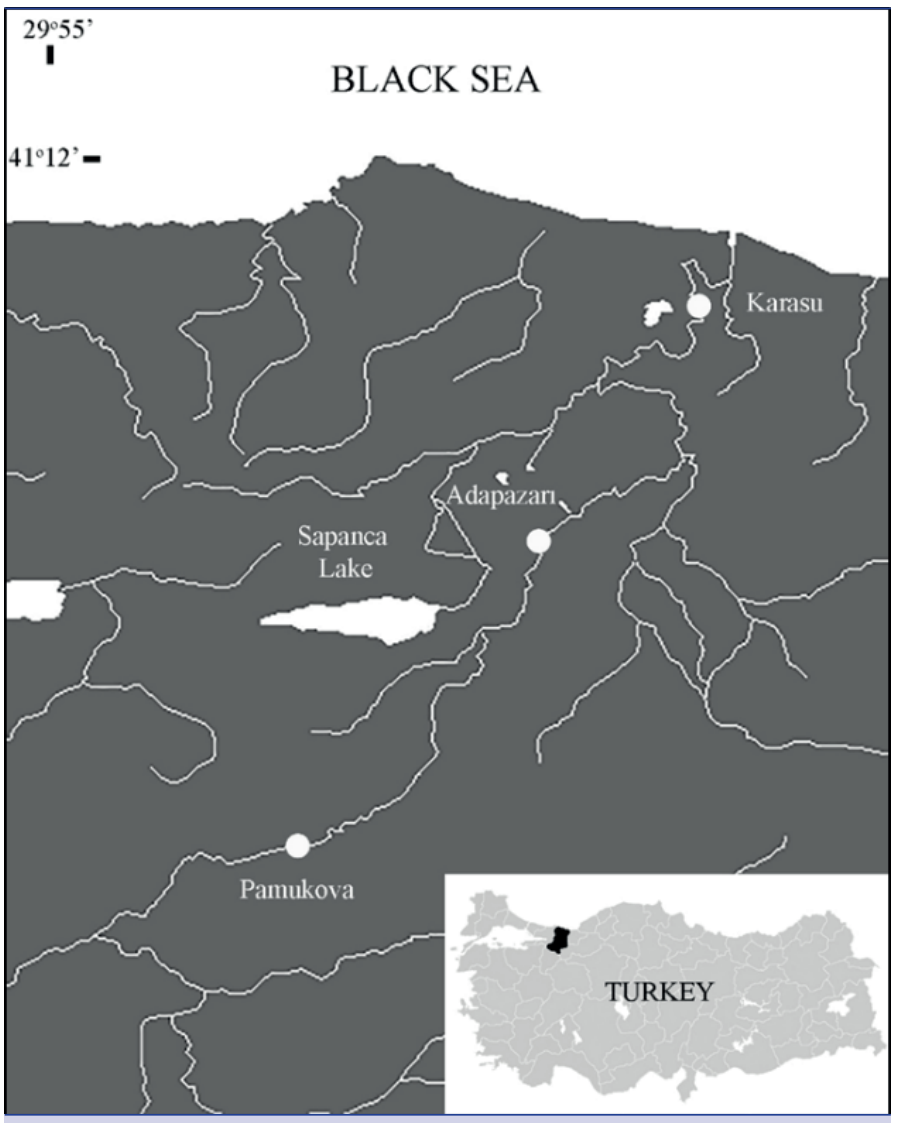

Figure 1. Study area

The samples were brought to the laboratory and the fish species were determined according to their diagnostic characteristics (Kottelat \& Freyhof, 2007). Total lengths and weights of samples were measured with measuring boards $(0.1 \mathrm{~cm})$ and precision balance $(0.01 \mathrm{~g})$. Scales were used to determine the age of the fish. The scales were taken from the area between the dorsalfin and the lateral line on the left side of the fish by forceps and placed in numbered envelopes (Lagler, 1966). Scales were removed from the envelopes and placed in petri dishes, containing $3 \% \mathrm{NaOH}$ solution, in order to be purified from foreign bodies. Randomly selected scales were examined under a binocular microscope (Chugunova, 1963).

Growth parameters were investigated by applying the von Bertalanffy growth function. The von Bertalanffy growth function was calculated as follows: $L_{t}=L_{\infty}\left(1-e^{-k(t-t o)}\right)$ (von Bertalanffy, 1957), where $L_{t}$ is length at age $t, L_{\infty}$ is asymptotic length, $k$ is the growth coefficient, and $t_{0}$ is the hypothetical age at which length is equal to zero (Ricker, 1975).

The growth performance index was calculated by the equation of Pauly \& Munro (1984):

$\phi^{\prime}=\log k+2 \log L_{\infty}$

\section{RESULTS AND DISCUSSION}

In this study, all samples were analyzed to estimate age and growth parameters, including five fish species from the Lower Sakarya River, Turkey. The parameters shown in Table 1 included sample size (n), range of total length (TL) and body weight (W), and standard error (SE).

The von Bertalanffy's growth model was calculated Lt = 92.18(1-e $\left.-\mathrm{e}^{-0.054(t+0.040)}\right)$ for A. brama, $L t=69.40\left(1-\mathrm{e}^{-0.040(t+0.030)}\right)$ for B. bjoerkna, Lt $=51.09\left(1-e^{-0.114(t+0.024)}\right)$ for C. gibelio, Lt $=48.11\left(1-e^{-0.088(t+0.023)}\right)$ for $R$. rutilus and $L t=41.74\left(1-e^{-0.104(t+0.035)}\right)$ for $V$. vimba. The asymptotic length $(L \infty)$, growth coefficient $(k)$, hypothetical age $\left(t_{0}\right)$ and growth performance index $\left(\phi^{\prime}\right)$ were shown in Table 2.

This study is the first assessment of the age and growth of $A$. brama, B. bjoerkna, C. gibelio, R. rutilus and $V$. vimba in the lower Sakarya River. The growth parameters $\left(L \infty, K, t_{0}, \phi^{\prime}\right)$ studied by different authors are given from other water areas (Table 3).

It was determined that the age composition of $A$. brama individual sex tend to $2^{+}-9^{+}$ages. The age composition results of different researches were given in Table 4 for A. brama. Asymptotic length value was higher when compared to previous studies for A. brama (Table 3). In contrast, $k$ value is lower than other studies. According to the growth performance index results, it can be said that A. brama showed average development in conditions of the lower Sakarya River.

The maximum age of $B$. bjoerkna in this study was $10^{+}$years which is higher than that of reported studies in Table 4. These differences may be due to the variations in sampling method and period, potential aging errors, and overfishing. The $L \infty$ value obtained in this study was higher than that in earlier researches. In the present study, the $k$ value was found to be lower than that found by other researchers (Table 3). Ma, Xie, Huo, Yang \& Huang,(2010) reported that different size distributions in different study may be the causes of differences among all of the estimated parameters.

The age composition of C. gibelio individuals was between $1^{+}$$7^{+}$in the present study. Some differences were observed in age groups of C. gibelio when compared to previous researches 


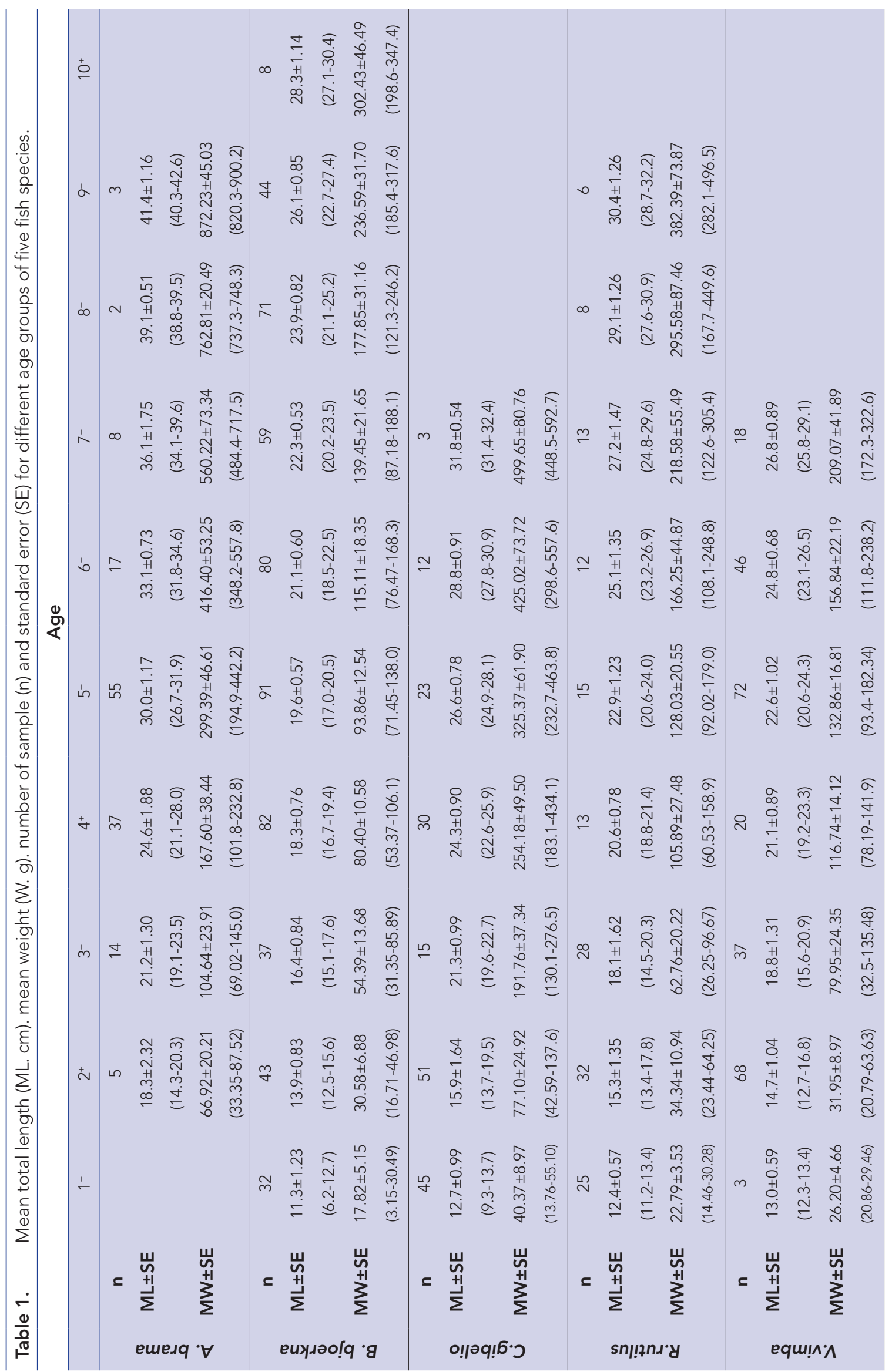


Table 2. Growth parameters $\left(L_{\infty}, k, t_{0}\right)$ and growth performance index $\left(\varnothing^{\prime}\right)$ for five fish species.

\begin{tabular}{llllll}
\hline Species & $\mathbf{N}$ & $\mathbf{L}_{\infty}$ & $\mathbf{k}$ & $\mathbf{t}_{\mathbf{0}}$ & $\boldsymbol{\sigma}^{\prime}$ \\
\hline Abramis brama & 141 & 92.18 & 0.054 & -0.040 & 2.628 \\
Blicca bjoerkna & 547 & 69.40 & 0.04 & -0.030 & 2.268 \\
Carassius gibelio & 179 & 51.09 & 0.114 & -0.024 & 2.474 \\
Rutilus rutilus & 152 & 48.11 & 0.088 & -0.023 & 2.307 \\
Vimba vimba & 264 & 41.74 & 0.104 & -0.035 & 2.260
\end{tabular}

Table 3. Growth parameters $\left(\boldsymbol{L}_{\infty}, \boldsymbol{k}, \mathbf{t}_{0}\right)$ and growth performance index $\left(\varnothing^{\prime}\right)$ for five fish species studied by different authors.

\begin{tabular}{|c|c|c|c|c|c|c|c|}
\hline Species & Location & $\mathbf{N}$ & $L_{\infty}$ & $k$ & $t_{0}$ & $\phi^{\prime}$ & References \\
\hline \multirow{4}{*}{$\begin{array}{l}\frac{\alpha}{0} \frac{0}{0} \frac{\pi}{0} \\
\frac{\pi}{0}\end{array}$} & Dąbie Lake & 290 & $44.62^{* * *}(T L)$ & 0.175 & 0.23 & 2.542 & Kompowski, 1988 \\
\hline & Volvi Lake & 443 & $50.7^{*}(\mathrm{FL})$ & 0.094 & -0.41 & 2.383 & Valoukas \& Economidis, 1996 \\
\hline & Rubikiai Lake & 209 & $65.7^{* \star *}(\mathrm{SL})$ & 0.085 & 0.482 & 2.565 & Žiliukienẻ \& Žiliukas, 2011 \\
\hline & Sakarya River & 141 & $92.18^{* * *}(\mathrm{TL})$ & 0.054 & -0.01 & 2.628 & This study \\
\hline \multirow{5}{*}{ 芯 } & Berounka River & & $23.4^{* \star *}(S L)$ & 0.270 & -0.27 & 2.169 & Hanel, 1991 \\
\hline & Balaton Lake & 127 & $35.9^{* \star *}(\mathrm{SL})$ & 0.098 & -0.639 & 2.101 & Specziár et al., 1997 \\
\hline & Sapanca Lake & 350 & $31.91^{*}(\mathrm{TL})$ & 0.122 & -1.087 & 2.10 & Okgerman et al., 2012 \\
\hline & Ladik Lake & 434 & $32.85^{\star \star *}(\mathrm{FL})$ & 0.11 & -2.64 & 2.074 & Yilmaz et al., 2015 \\
\hline & Sakarya River & 547 & $69.4^{* * *}(\mathrm{TL})$ & 0.04 & -0.02 & 2.268 & This study \\
\hline \multirow{5}{*}{ 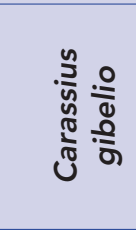 } & Lysimachia Lake & & $32.5^{* * *}(\mathrm{FL})$ & 0.282 & -0.51 & 2.47 & Leonardos et al., 2001 \\
\hline & Egirdir Lake & 616 & $33.3^{* \star *}(\mathrm{FL})$ & 0.346 & -0.302 & 2.58 & Balık et al., 2004 \\
\hline & Aksu River & 128 & $36.86^{\star \star \star}(T L)$ & 0.244 & -0.791 & & İnnal, 2012 \\
\hline & Seyhan River & 317 & $32.30^{* * *}(T L)$ & 0.307 & -0.526 & 2.505 & Ergüden, 2015 \\
\hline & Sakarya River & 177 & $51.09^{* * *}(\mathrm{TL})$ & 0.11 & -0.02 & 2.458 & This study \\
\hline \multirow{5}{*}{ 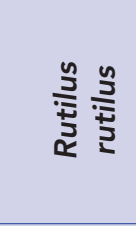 } & Volvi Lake & 233 & $33.3^{* \star *}(T L)$ & 0.081 & -1.30 & 1.95 & Papageorgiou, 1979 \\
\hline & Berounka River & & $28.5^{\star \star \star}(\mathrm{SL})$ & 0.169 & -0.17 & 2.14 & Hanel, 1991 \\
\hline & Balaton Lake & 112 & $31.9^{* * *}(\mathrm{SL})$ & 0.160 & 0.026 & 2.21 & Specziár et al., 1997 \\
\hline & Sapanca Lake & 136 & $31.87^{* *}(T L)$ & 0.195 & -0.034 & 2.297 & Okgerman et al., 2009 \\
\hline & Sakarya River & 152 & $48.11^{* \star *}(\mathrm{TL})$ & 0.09 & -0.02 & 2.318 & This study \\
\hline \multirow{4}{*}{ 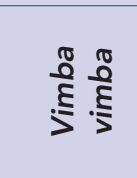 } & Berounka River & & $27.8^{\star \star \star}(\mathrm{SL})$ & 0.212 & -0.22 & 2.214 & Hanel, 1991 \\
\hline & Caspian Sea coast & 845 & $26.1^{\star \star \star}(\mathrm{FL})$ & 0.280 & -0.65 & 2.280 & Chaichi et al., 2011 \\
\hline & Sapanca Lake & 217 & $24.70^{*}(\mathrm{FL})$ & 0.205 & -1.464 & 2.097 & Okgerman et al., 2011 \\
\hline & Sakarya River & 264 & $41.74^{* * *}(T L)$ & 0.10 & -0.04 & 2.241 & This study \\
\hline
\end{tabular}

(Table 4). These differences may be due to the sampling method, fishing activity, feeding habitats, population density and the ecological condititions of water bodies.

The ages and lengths of the $R$. rutilus ranged between $1^{+}-9^{+}$ years, 11.2 to $32.2 \mathrm{~cm}$ in the lower Sakarya River (Table 1). In other research on $R$. rutilus, age distribution was reported to be $1^{+}$$6^{+}$(Sedaghat \& Hoseini, 2012) in the Southern Caspian Sea, $1^{+-}$ $4^{+}$in Seyhan Dam Lake (Ergüden, Ergüden, \& Göksu, 2008). Due to the maximum size obtained in the sampling, asymptotic length value calculated for $R$. rutilus was found higher compared to the research in Table 3.

Despite wide distribution of $\mathrm{V}$. vimba individuals, information on the biology of this species in Turkey is scarce. The age composi- tion of this species was between $1^{+}-7^{+}$in the present study. The growth rate for length and weight in this research was generally high in comparison with populations from other studies (Table 4). The growth performance index of $\mathrm{V}$. vimba ( $\left.\phi^{\prime}\right)$ in the lower Sakarya River was similar to that previously reported, apart from $2.097\left(\phi^{\prime}\right)$ V. Vimba caught in the Sapanca Lake (Okgerman, Elp, \& Yardımcı, 2011). The differences in the growth of Vimba between regions might have been because of the ecological condititions of the Sakarya River, competition for food between Vimba and the other fish species and differences on condition, length, age, sex, and gonadal development of V. vimba (Ricker, 1975).

Growth can be evaluate when age and size information are combined. Growth provides us with some indication of resource utilization and the effectiveness of our management strategies. 


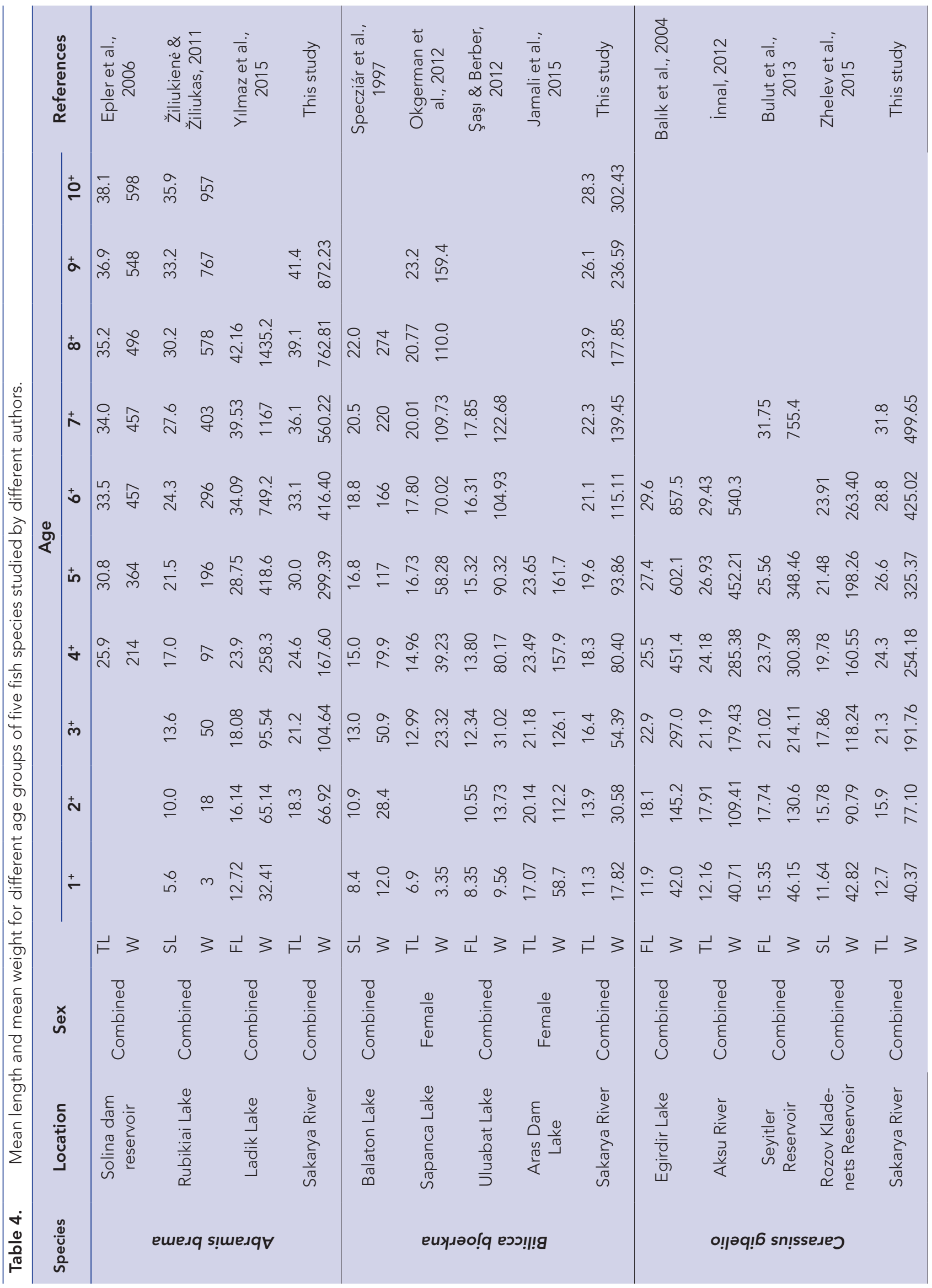




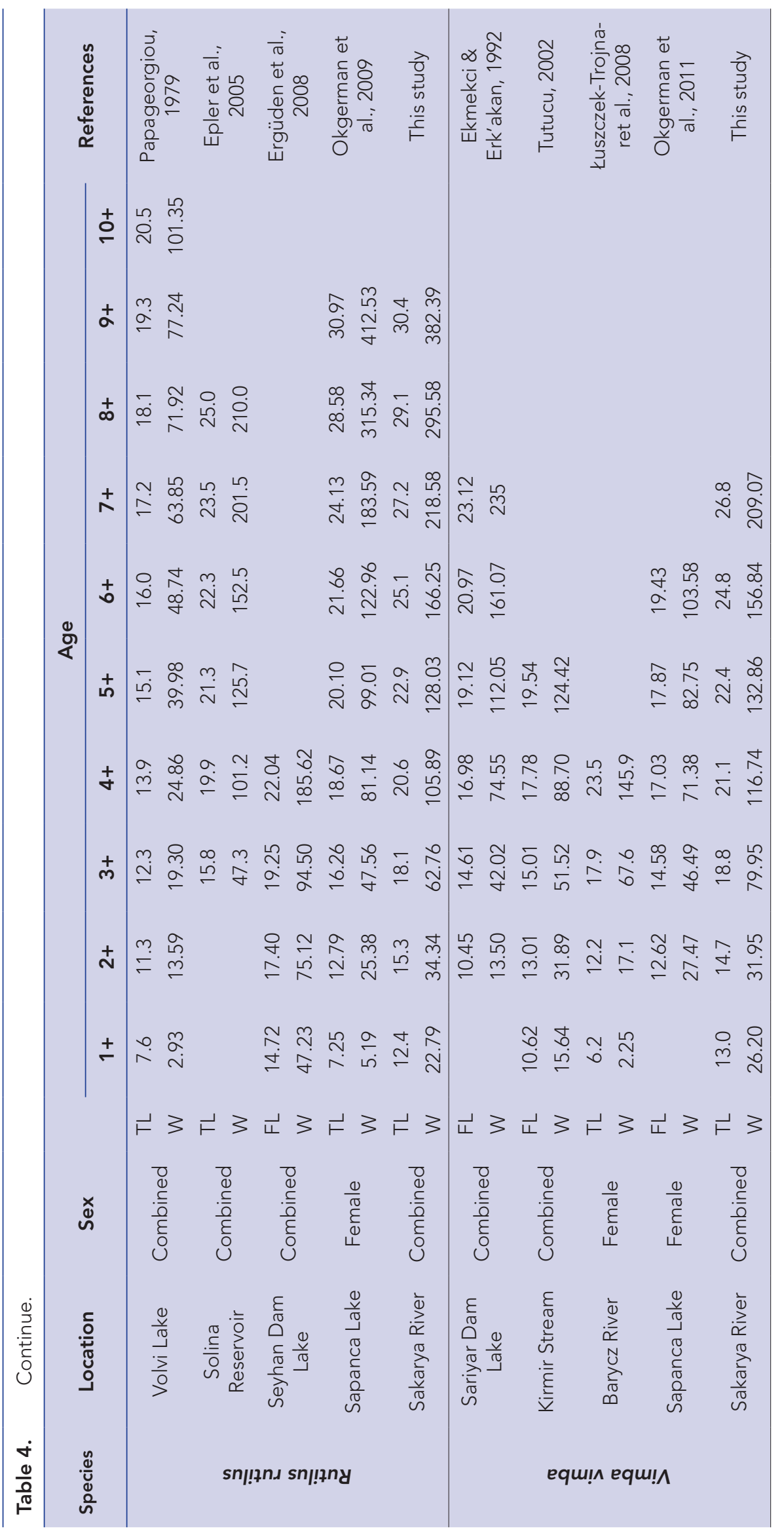


When we evaluate age and growth in combination, the relationship between population size and biomass can be easier to understand. This understanding is the basis of modern fisheries resource allocation and management.

\section{CONCLUSION}

In conclusion, this study provides basic information on age and growth of A. brama, B. bjoerkna, C. gibelio, R. rutilus and V. vimba living in the lower Sakarya River. The results of this study are useful for evaluating the relative condition of fishery managements and stock assessment in the Sakarya River. Also, this study will contribute to further scientific studies in the same area.

Acknowledgements: We would like to thank Dr. İrem KÖSE REIS and all fishermen for their help.

Ethics Committee Approval: Legal research ethics committee approval permissions for the survey were obtained from the Adnan Menderes University, Animal Experiments Local Ethics Committee.

Financial Disclosure: This study was funded by Muğla Sıtkı Koçman University, Scientific Research Project Office with Project number 17/073.

Conflict of Interest: The authors have no conflicts of interest to declare.

\section{REFERENCES}

Bulut, S., Ramazan, M., Algan, B., Özbek, M., Bülent, U. \& Konuk, M. (2013). Several growth characteristics of an invasive Cyprinid fish (Carassius gibelio Bloch, 1782). Notulae Scientia Biologicae. [CrossRef]

Campana, S. E. \& Thorrold, S. R. (2001). Otoliths, increments, and elements: keys to a comprehensive understanding of fish populations? Canadian Journal of Fisheries and Aquatic Sciences. [CrossRef]

Chaichi, A., Vosoughi, G., Kaymaram, F., Jamili, S. \& Fazli, H. (2011). Population dynamics of Vimba vimba persain Iranian waters of the Caspian Sea. Cybium, 35(3), 237-243.

Chugunova, N. I. (1963). Age and Growth Studies in Fish. Israel Prog. Sci. Transl. No: 610, Natl. Sci. Found Washington, D.C. pp 132.

Eschmeyer, W. N., Fricke R. \& Van der Laan, R. (Eds.), (2017). Catalog of Fishes. http://researcharchive.calacademy.org/research/ichthyology/ catalog/fishcatmain.asp

Ekmekçi, F. G. \& Erk'akan, F. (1992). Some of the Growth and Reproduction Properties of Vimba vimba tenella (Nordmann, 1840) in Sarıar Dam Lake. Doga-Tr J of Zoology, 16, 323-341.

Emiroğlu, O. S. M. (2011). Alien fish species in upper Sakarya River and their distribution. African Journal of Biotechnology, 10(73), $16674-$ 16681. [CrossRef]

Epler, P., Popek, W., Luszczek-Trojnar, E., Drag-Kozak, E., Szczerbik, P. \& Socha, M. (2005). Age and growth rate of the roach (Rutilus rutilus L.) from the Solina and the Tresna (Zywieckie Lake) dam reservoires. Acta Scientiarum Polonorum, 4, 59-70.

Epler, P., Lauszczek-Trojnar, E., Drag-Kozak, E., Szczerbik, P., Popek, W. \& Socha, M. (2006). Age and growth of bream (Abramis brama L.) in the Solina, Tresna and Roznow dam reservoires, Acta Scientiarum Polonorum, 5(1), 45-56.

Ergüden, S. A., Ergüden, D. \& Göksu, M. Z. L. (2008). Growth Properties of Roach (Rutilus rutilus L., 1758) in Seyhan Dam Lake (Adana). Journal of FisheriesSciences.com. [CrossRef]
Ergüden, S. A. (2015). Age and Growth Properties of Prussian Carp, Carassius gibelio (Bloch, 1782) Living in the Middle Basin of Seyhan River in Adana, Turkey. Pakistan Journal of Zoology, 47(5), 1365-1371.

Hanel, L. (1991). Growth of four cyprinid fishes in the river Berounka (Czech Republic). Zivocisna Vyroba, 36, 929-937.

innal, D. (2012). Age and growth properties of Carassius gibelio (Cyprinidae) living in Aksu river Estuary (Antalya-Turkey). Review of Hydrobiology, 5(2), 97-109.

Jamali, H., Eagderi, S., Esmaeilzadegan, E. \& Patimar, R. (2015). Age, growth and some biological characteristics of Silver bream (Blicca bjoerkna L., 1758) (Cyprinidae) from Aras Dam Lake in Northwest of Iran. International Journal of Aquatic Biology.

Kahraman, A. E., Göktürk, D. \& Aydın, E. (2014). Length-Weight Relationships of Five Fish Species from the Sakarya River, Turkey. Annual Research \& Review in Biology. [CrossRef]

Kompowski, A. (1988). Growth rate of freshwater bream, Abramis brama (L., 1758), in Lake Dąbie and the Szczecin Lagoon. Acta Ichthyologica et Piscatoria. [CrossRef]

Korkmaz, A. Ş.\& Zencir Tanır, Ö. (2016). Fish Species Biodiversity in Kirmir Stream of Sakarya River, Journal of Limnology and Freshwater Fisheries Research. [CrossRef]

Kottelat, M. \& Freyhof, J. (2007). Handbook of European freshwaterf ishes. Publications Kottelat, Cornol and Freyhof, Berlin. 646 p.

Lagler, K.F. (1966). Freshwater fishery biology. W.M.C. Brown Company Publishers Dubuque, lowa.

Leonardos, I., Katharios, P. \& Charisis, C. (2001). Age, growth and mortality of Carassius auratus gibelio (Linnaeus, 1758) (Pisces: Cyprinidae) in Lake Lysimachia. p. 257-259. In Proceedings of theTenth Ichthyological Congress, 18-22 October 2001, Chania, Greece.

Łuszczek-Trojnar, E., Drąg-Kozak, E., Kleszcz, M., Popek, W. \& Epler, P. (2008). Gonadal maturity in vimba (Vimba vimba L.) raised in carpponds. Journal of Applied Ichthyology. [CrossRef]

Ma, B. S., Xie, C. X., Huo, B., Yang, X. F. \& Huang, H. P. (2010). Age and growth of a long-lived fish Schizothorax O'connori in the Yarlung Tsangpo River, Tibet. Zoological Studies, 49(6), 749-759.

Memiş, D., Tosun, D. D., Yamaner, G., Tunçelli, G., \& Gessner, J. (2019). Present Status of Sturgeon in the Lower Sakarya River in Turkey. Aquatic Research, 2(2), 53-60. [CrossRef]

Nelson, J. S. (1994). Fishes of the World. New York: John Wiley \& Sons. ISBN 0471547131.

Okgerman, H., Oral, M. \& Yigit, S. (2009). Biological aspects of Rutilus rutilus (roach) in Sapanca Lake (Turkey). Journal of Animal and Veterinary Advances.

Okgerman, H., Elp, M. \& Yardimci, C.H. (2011). Growth, the length-weight relationship, and reproduction in Vimba (Vimba vimba L. 1758) sampled from an oligo-mesotrophic lake in northwest Anatolia (Turkey). Turkish Journal of Zoology. [CrossRef]

Okgerman, H., Elp, M. \& Atasagun, S. (2012). The growth and reproduction of White bream (Blicca bjoerkna L. 1758) in an oligo-mesotrophic lake in northwest Anatolia (Sapanca, Turkey). Turkish Journal of Biology. [CrossRef]

Ölmez, M. (1992). A study on the population dynamics on fishes in the Sakaryabaşı region of the upper Sakarya basin. [PhD thesis]. Ankara University. $228 \mathrm{~s}$.

Papageorgiou, N. K. (1979). The length weight relationship, age, growth and reproduction of the roach Rutilus rutilus (L.) in Lake Volvi. Journal of Fish Biology. [CrossRef]

Pauly, D. \& Munro, J. L. (1984). Once more on the comparison of growth in fish and invertebrates. Fishbyte (Philippines), 1, 21-22.

Reis, i., Cerim, H., \& Ates, C. (2019). Length-weight relationship of 13 fishspecies from the Lower Sakarya River, Turkey. Aquatic Sciences and Engineering. [CrossRef]

Ricker, W. E. (1975). Computation and interpretation of biological statistics of fish populations. Bulletin Fisheries Research Board of Canada, 191, 1-382. 
Şaşı, H. \& Berber, S. (2012). Age, growth and some biological characteristics of White bream (Blicca bjoerkna L., 1758) in Uluabat Lake, in northwestern of Anatolia. Asian Journal of Animal and Veterinary Advances. [CrossRef]

Sedaghat, S. \& Hoseini, S. A. (2012). Age and Growth of Caspian Roach, Rutilus rutilus caspicus (Jakowlew, 1870) in Southern Caspian Sea, Iran. World Journal of Fish and Marine Sciences.

Şengörür, B. \& İsa, D. (2001). Factor analysis of water quality observations in the Sakarya River. Turkish Journal of Engineering and Environmental Sciences, 25(5), 415-426.

Shiklomanov, I. A. (1999). World water resources and their use. St. Petersburg, Russia: State Hydrological Institute / UNESCO.

Specziár, A., Tölg, L. \& Bíró, P. (1997). Feeding strategy and growth of cyprinids in the littoral zone of Lake Balaton. Journal of Fish Biology. [CrossRef]

Tutucu, S. (2002). Investigated of Some Biological Characteristics of vimba (Vimba vimba tenella (Nordmann, 1840)) in Kirmir Stream of Sakarya River. Natural Sciences Institute. M.Sc. thesis, Gazi University, pp 53.
Valoukas, V. A. \& Economidis, P. S. (1996). Growth, population composition and reproduction of bream Abramis brama (L.) in Lake Volvi, Macedonia, Greece. Ecology of Freshwater Fish. [CrossRef]

Von Bertalanffy, L. (1957). Quantitative laws in metabolism and growth. The Quarterly Review of Biology. [CrossRef]

Yılmaz, S., Yazıcıoğlu, O., Yazııı, R. \& Polat, N. (2015). Age, Growth and Reproductive Period of White Bream, Blicca bjoerkna (L., 1758) in Lake Ladik, Turkey. Journal of Limnology and Freshwater Fisheries Research. [CrossRef]

Zhelev, Z., Boyadzhiev, P. \& Angelov, M. (2015). Analysis of Size-Age, Sexual Structure and Condition of Populations of Carassius gibelio (Pisces: Cyprinidae) from two Water Basins in Galabovo Region (Southern Bulgaria). Trakia Journal of Sciences. [CrossRef]

Žiliukienė, V. \& Žiliukas, V. (2011). Growth rate of freshwater bream (Abramis brama (L.)) in Lake Rubikiai (Lithuania). Acta Zoologica Lituanica. [CrossRef] 